Indonesian Journal for Social Responsibility (IJSR) Vol. 2, No. 01, (2020), hal. 21-28

\title{
KEGIATAN PEMBUATAN KOMPOSTING PADAT DENGAN PROSES FERMENTASI DI DESA CIANTING UTARA KABUPATEN PURWAKARTA
}

\author{
Azafilmi Hakiim ${ }^{1 *}$, Ulinnuha Latifa ${ }^{2}$, Cintiya Septa Hasannah ${ }^{3}$, Dessy Agustina Sari ${ }^{4}$ \\ ${ }^{13} 4$ Program Studi Teknik atau Rekayasa Kimia, ${ }^{2}$ Program Studi Teknik Elektro, \\ Fakultas Teknik, Universitas Singaperbangsa, Karawang, Indonesia \\ E-mail: 1azafilmi.hakiim@staff.unsika.ac.id*
}

Received: April 30, 2020 / Revised: June 29, 2020 / Accepted: June 30, 2020

DOI: https://doi.org/10.36782/ijsr.v2i1.32

\begin{abstract}
ABSTRAK
Sampah merupakan impuritas yang tidak memiliki nilai pakai kembali dari kegiatan aktivitas manusia sehari-hari baik di lingkungan domestik maupun industri. Salah satu fokus dari tim pengabdian dalam hal ini adalah sampah organik yang bersumber pada lingkungan domestik (rumah tangga) dengan cara pengolahan secara pengomposan. Tujuan dari kegiatan pengabdian ini menghasilkan kemandirian warga desa Cianting Utara dalam hal pengelolaan sampah organik. Metodologi pelaksanaan dilakukan melalui lima tahapan yakni identifikasi masalah (Desa Mitra), penyusunan program kegiatan pengelolaan sampah organik, pembuatan komposting padat, pelaksanaan program kegiatan, evaluasi program kegiatan. Pembuatan komposting padat dilakukan dengan pembuatan fermentor secara anaerob, pencampuran media komposting, dan pencampuran sampah organilk rumah tangga. Hasil dari panen komposting padat tersebut kemudian diimplementasikan pada tanaman sayuran tomat dan dilakukan pengamatan. Hasil dari tingkat kesuburan yang ditunjukkan berdasarkan parameter panjang rata-rata 24 hari pemeliharaan $14,5 \mathrm{~cm}$ per tanaman dan jumlah lembar daun 9-15 per tanaman. Responden berjumlah 15 memberikan penilaian pada form yang dibagikan menunjukkan persentase kepuasan 98\% dari indicator penyampaian tujuan, komunikasi penyampaian materi, implementasi praktek, dan pengetahuan tanya jawab. Indikator tertinggi pada penyampaian materi serta implementasi tanya jawab.
\end{abstract}

Kata kunci: anaerob, fermentor, komposting, organic, sampah

\begin{abstract}
Waste is an impurity that has no reuse value from daily human activities in both the domestic and industrial environments. One focus of the service team in this case is organic waste sourced from the domestic environment (household) by composting. The purpose of this community service activity is to create independence for the residents of Cianting Utara village in terms of organic waste management. The methodology of implementation is carried out through five stages namely identification of problems (Partner Village), compilation of organic waste management program activities, making solid composting, implementing program activities, evaluating program activities. Solid composting is done by making fermentors anaerobically, mixing composting media, and mixing household organic waste. The results of the solid
\end{abstract}


composting harvest are then implemented on the tomato vegetable plant and observed. The results of the fertility level are shown based on the average length parameter 24 days maintenance $14.5 \mathrm{~cm}$ per plant and the number of leaves $9-15$ per plant. A total of 15 respondents gave an assessment of the form distributed showing a 98\% satisfaction percentage of the indicators of goal delivery, communication of material delivery, practice implementation, and question and answer knowledge. The highest indicator in the delivery of material and the implementation of questions and answers.

Keywords: anaerobes, composting, fermentors, organic, waste

\section{PENDAHULUAN}

Sampah merupakan impuritas yang tidak memiliki nilai pakai kembali dari kegiayan aktivitas manusia sehari-hari baik dilingkungan domestik maupun dilingkungan industri. Salah satu fokus dari tim pengabdian dalam hal ini adalah sampah organik yang bersumber pada lingkungan domestik (rumah tangga). Umumnya sampah organik dikalangan masyarakat masih minim dilakukan pemanfaatan kembali, sehingga kerap hanya menimbulkan bau busuk atau sumbatan pada selokan-selokan jalanan. Sasaran mitra yang menjadi fokus tim pengabdian adalah daerah Cianting Utara yang terletak di pinggir pantura wilayah kabupaten Purwakarta. Survey yang dilakukan tim mengenai kondisi desa, memberikan beberapa informasi bahwa keberadaan desa yang dinilai berdebu dan banyaknya sampah yang menumpuk didepan rumah rumah warga, serta terlihat sumbatan pada selokan kotor berlumut. Selain itu pengelolaan sampah yang selama ini dilakukan masih sebatas menunggu petugas kebersihan (bagi warga yang ikut iuran bulanan sampah) untuk kemudian dikumpulkan akhir di TPA, sebagianya lagi mengelola sampah organik dengan cara dibakar. Sampah yang menggunung di TPA menyebabkan meningkatnya degradasi kebersihan lingkungan karena mengeluarkan gas metan yang menyebabkan global warming, gas ini memiliki daya rusak 23 kali lebih kuat dari karbon (Dias, 2009; Sony, 2010: Banowati, 2011). Sedangkan sampah yang dibakar menyebabkan polusi udara dan abu yang bertebaran. Sehingga perlu adanya kegiatan yang mampu menggerakkan warga desa untuk mampu mengolah dan memanfaatkan sampah secara mandiri pada pekarangan rumah masing-masing. Pupuk organik memiliki peranan yang sangat penting bagi kesuburan tanah, karena penggunaan pupuk organik pada budidaya tanaman pangan dan non pangan dapat memperbaiki sifat fisik, kimia maupun biologis tanah. Kelebihan lain dari pupuk organik yaitu tidak memiliki kandungan zat kimia yang tidak alami, sehingga lebih aman dan lebih sehat bagi manusia, terlebih bagi tanah pertanian itu sendiri (Sutrisno, E. \& Priyambada, I.B., 2019) 
Beberapa cara pengolahan sampah organik diantaranya: pertama, Sanitary landfill merupakan model pengolahan sampah dengan mengurug sampah ke dalam tanah, dengan menyebarkan sampah secara lapis per lapis pada sebuah lahan yang telah disiapkan. Setiap lapisan dipadatkan untuk ditimbun dengan sampah berikutnya. Sanitary landfill ini yang paling banyak diterapkan di tempat pembuangan akhir (TPA) di Indonesia. Pada akhir operasi, biasanya TPA ditutup dengan lapisan tanah. Sanitary landfill pada dasarnya dirancang untuk penanganan sampah secara sehat. Artinya TPA dirancang semaksimal mungkin untuk tidak mencemari lingkungan, misalnya dengan memberi lapisan kedap air pada dasar landfill, membuat saluran air lindi, pemipaan gas dan penutupan dengan lapisan tanah secara reguler (Marfuatun, 2013).

Metode penggunaan sanitary landfill mengurangi jumlah sampah ke TPA (Khuzzaman dkk., 2013). Kelemahan dari model sanitary landfill adalah memerlukan lahan yang luas. Sehingga model ini sulit untuk diterapkan di kotakota besar, karena ketersedian lahan yang terbatas (Marfuatun, 2013). Metode Kedua Insinerasi proses pembakaran sampah yang terkendali menjadi gas dan abu. Alat incinerasi disebut incinerator. Gas yang dihasilkan adalah karbondiokasida dan gas-gas yang lain yang kemudian dilepaskan ke udara. Sedangkan abunya dibuang ke TPA atau dicampur dengan bahan lainnya sehingga menjadi produk berguna. Kekurangan dari model insinerasi ini adalah kemungkinan adanya polusi udara dari gas buang. Polusi tersebut umumnya disebabkan oleh desain incinerator yang tidak sempurna. akan menyebabkan terjadinya polusi udara oleh gas buangnya. Selain itu, model ini juga memerlukan biaya operasional yang besar (Marfuatun, 2013). Metode ketiga yaitu dengan cara pengomposan. Pengkomposan adalah proses biologi yang dilakukan oleh mikroorganisme untuk mengubah limbah padat organik menjadi produk yang stabil menyerupai humus.

Pengomposan pada dasarnya merupakan upaya mengaktifkan kegiatan mikrobia agar mampu mempercepat proses dekomposisi bahan organik. Yang dimaksud mikrobia disini bakteri, fungi dan jasad renik lainnya. Proses pengkomposan pada dasarnya dapat dibagi dua jenis yaitu aerobik dan anaerobik. Aerobik artinya kondisi pengomposan membutuhkan oksigen. Anaerobik artinya kondisi pengomposan tanpa bantuan oksigen (Marfuatun, 2013; Walidaini, 2016; Mehl, Jessica A., 2008).

Pembuatan kompos membutuhkan aktivator untuk mempercepat proses kematangan kompos. Selain menggunakan aktivator komersial, dapat digunakan bioaktivator dengan memanfaatkan mikroorganisme lokal (MOL). Larutan $\mathrm{MOL}$ merupakan hasil fermentasi yang dapat dibuat dari berbagai bahan yang tersedia di lingkungan sekitar kita. Larutan ini mengandung 
mikroorganisme yang dapat merombak bahan organik, merangsang pertumbuhan tanaman dan sebagai agen pengendali hama penyakit tanaman (Sutari, 2009; Purwasasmita, 2009).

Pada proses pengomposan dinilai memiliki biaya pengerjaan yang minim dan sangat bisa diterapkan masing-masing warga desa Cianting Utara. Tim pengabdian memberikan upaya edukasi dan pelatihan dalam penanganan sampah organik dengan metode pengomposan anaerob.

\section{METODOLOGI}

Pada implementasi kegiatan ini melibatkan peran masyarakat penggerak yaitu perangkat desa (6 orang) dan ibu-ibu PKK (15 orang). Tahapan ini dilakukan dari awal yang meliputi :

- Identifikasi masalah (Desa Mitra)

- Penyusunan Program Kegiatan Pengelolaan Sampah Organik

- Pembuatan Komposting Padat

- Pelaksanaan Program Kegiatan (Praktek Pembuatan Komposting Padat dan Implementasi pada tanaman)

- Evaluasi Program Kegiatan.

1. Identifikasi masalah dilakukan dengan survey awal keberadaan desa mitra, dan wawancara warga setempat.

2. Penyusunan program kegiatan dilakukan dengan cara merancang kebutuhan yang digunakan dalam kegiatan tersebut dan mengkomunikasikan kepada perangkat desa dan jajarannya pada acara minggon desa untuk mengadakan kegiatan tersebut.

3. Pembuatan komposting padat dilakukan dengan mengumpulkan bahan yang terdiri dari:
a. keranjang kayu buah bekas
b. kain atau karung penutup keranjang
c. tanah satu ember
d. sekam satu ember
e. larutan fermentasi (larutan gula merah, piyem, dan tempe)
f. air 3 liter
g. penutup keranjang dari karpet bekas

Cara Pembuatan Komposting Padat: buat Larutan Fermentasi (starter/nutrient support): Tempe (belum matang) + piyem (tapai fermentasi) $1 / 4 \mathrm{~kg}+$ air gula merah yang sudah dilarutkan dalam 1 liter air + 3 liter air (setelah larutan fermentasi jadi) simpan selama satu minggu tutup dengan plastik hitam dan jauhkan dari sinar matahari langsung.

a. Setelah fermentor jadi, maka siapkan sekam 1 (ember kecil) dan tanah 1 (ember kecil);

b. Campur hingga rata bersama larutan fermentor, dan masukkan pada media komposting, tunggu hingga dua hari;

c. Setelah dua hari masukkan potongan sayur/buah, tulang ikan/ nasi sisa pada media komposting, aduk dan timbun (jangan dimampatkan) (setelah itu ditunggu hingga 2 minggu; 
d. Silahkan diaplikasikan di pekarangaan tanaman anda.

4. Pelaksanaan program kegiatan dilakukan dengan koordinasi tim yang terdiri dari ketua dan anggota tim. Ketua bertugas mengkoordinasi awal berjalannya proses survey dan pembuatan proses komposting padat serta pelaksanaan program. Anggota bertugas mendampingi dan membantu kegiatan program tersebut terlaksana, serta evaluasi hasil program kegiatan tersebut.

5. Evaluasi kegiatan tersebut diolah berdasarkan tingkat kesuburan dari implementasi komposting padat.

\section{HASIL DAN PEMBAHASAN}

Kegiatan ini dilakukan selama 1 bulan yang dilakukan pada tanggal 1 Juli - 31 Juli 2019. Pelaksanaan kegiatan ini dilakukan dari temuan survey awal analisis sampah organik rumah tangga dan pembuatan composting sampah organic di hari pertama. Dalam pembuatan komposting padat, maka kurang lebih menunggu hingga 2 minggu berjalan untuk bisa kemudian diterapkan (Hari ke-14).

Hari ke-15 dilakukan pembuatan media tanam dari bambu, untuk kemudian di tempatkan polybag kecil-kecil dari bekas aqua sebagai media awal penanaman bibit sayuran tomat. Setiap harinya diberikan perlakuan penyiraman selama 3 kali sesi, yaitu pagi; siang dan sore hari. Pengamatan proses dilakukan dari sejak hari ke-15 tanam, dan terlihat di 2 hari kemudian mulai muncul kehijauan pada media tanam untuk sayuran tomat.

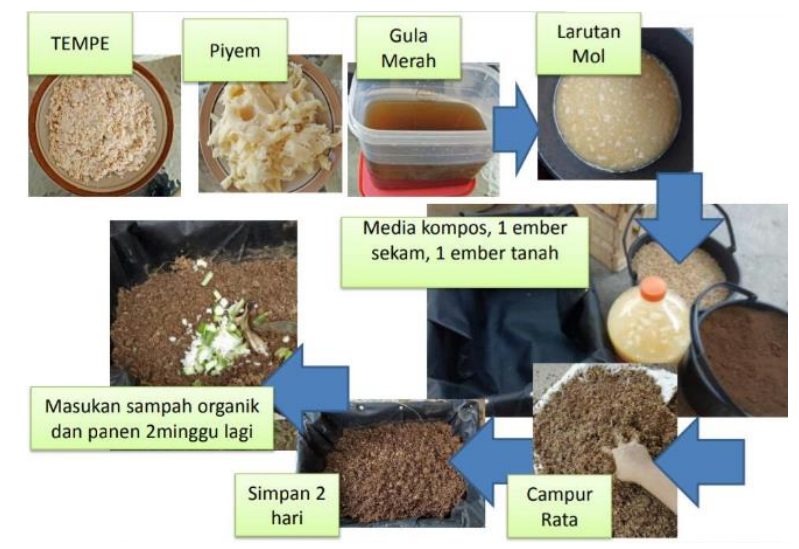

Gambar 1. Pembuatan komposting padat (Sumber: dokumentasi penulis)

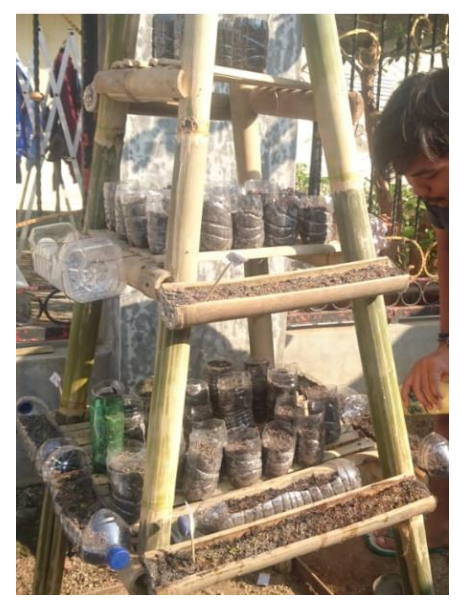

Gambar 2. Media tanam dari bambu dan polybag botol bekas

(Sumber: dokumentasi penulis)

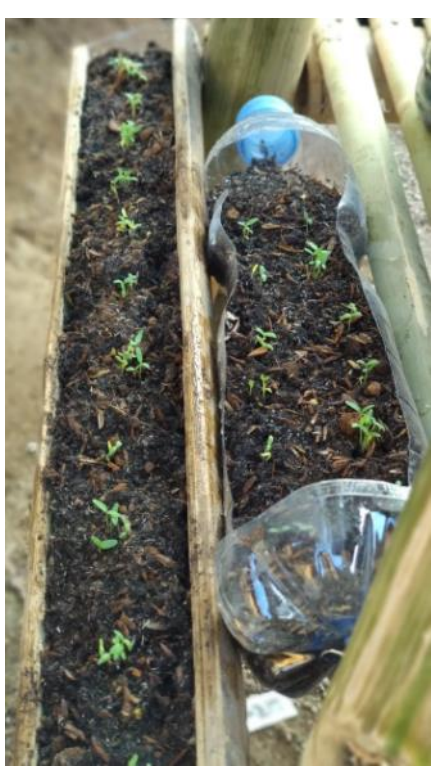

Gambar 3. Perkembangan Hari ke-17

(Sumber: dokumentasi penulis) 
Terlihat bahwa pada perbandingan di media polybag bambu dan plastik menunjukkan adanya pertumbuhan yang dinilai sama merata dan keduanya mampu sama sama berkembang. Setelah beberapa pengamatan, kemudian dipindahkan kemedia yang lebih besar dengan memanfaatkan kaleng bekas susu hari ke 24 .

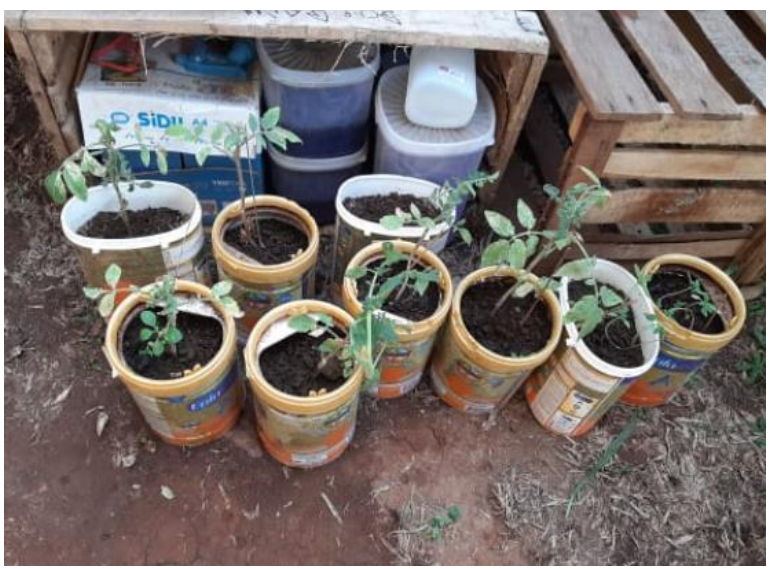

Gambar 4. Pemindahan beberapa sampel tanaman ke media yang lebih luas (kaleng bekas) (Sumber: dokumentasi penulis)

Tingkat kesuburan yang diperoleh dengan pengukuran panjang Persamaan (1) dan jumlah lebar daun sebagai berikut:

Pengukuran panjang untuk melihat pertambahan panjang tanaman berdasarkan hari ke 0-4, 5, 9-13,14- 24 dapat dilihat pada Persamaan (1) berikut ini,

$$
L=L t-L o
$$

Keterangan:

L : Pertambahan Panjang

Lt : Pertambahan panjang rata-rata pada akhir $(\mathrm{cm})$

Lo : Pertambahan panjang rata-rata pada awal $(\mathrm{cm})$
Perhitungan jumlah daun dihitung dari hari ke 0-24 hari:

Tabel 1. Pertumbuhan panjang

\begin{tabular}{ccccc}
\hline Tanaman & $\begin{array}{c}0-7 \\
\text { Hari }\end{array}$ & $\begin{array}{c}8-14 \\
\text { Hari }\end{array}$ & $\begin{array}{c}15-21 \\
\text { Hari }\end{array}$ & $\begin{array}{c}22-28 \\
\text { Hari }\end{array}$ \\
\hline 1 & 3,4 & 6,5 & 9,9 & 13,4 \\
$\mathrm{~cm}$ & $\mathrm{~cm}$ & $\mathrm{~cm}$ & $\mathrm{Cm}$ \\
\hline 2 & 3,1 & 6,2 & 9,6 & 13,5 \\
& $\mathrm{~cm}$ & $\mathrm{Cm}$ & $\mathrm{cm}$ & $\mathrm{cm}$ \\
\hline 3 & 3 & 6,2 & 9,7 & 13,4 \\
& $\mathrm{Cm}$ & $\mathrm{Cm}$ & $\mathrm{cm}$ & $\mathrm{cm}$ \\
\hline 4 & 3,1 & 6,3 & 9,6 & 13,5 \\
& $\mathrm{~cm}$ & $\mathrm{Cm}$ & $\mathrm{cm}$ & $\mathrm{cm}$ \\
\hline 5 & 3,2 & 6,2 & 9,7 & 13,7 \\
& $\mathrm{Cm}$ & $\mathrm{Cm}$ & $\mathrm{cm}$ & $\mathrm{cm}$ \\
\hline 6 & 3,3 & 6,3 & 9,8 & 13,8 \\
& $\mathrm{~cm}$ & $\mathrm{Cm}$ & $\mathrm{cm}$ & $\mathrm{cm}$ \\
\hline 7 & 2,9 & 6,6 & 9,8 & 14 \\
& $\mathrm{~cm}$ & $\mathrm{Cm}$ & $\mathrm{cm}$ & $\mathrm{cm}$ \\
\hline 8 & 3 & 6,5 & 9,9 & 14,2 \\
& $\mathrm{~cm}$ & $\mathrm{Cm}$ & $\mathrm{cm}$ & $\mathrm{cm}$ \\
\hline 9 & 3,7 & 6,4 & 9,9 & 14,5 \\
& $\mathrm{~cm}$ & $\mathrm{Cm}$ & $\mathrm{cm}$ & $\mathrm{cm}$ \\
\hline
\end{tabular}

Tabel 2. Perkembangan Jumlah daun dari hari 0-24 yang dihitung sekali pengamatan

\begin{tabular}{cc}
\hline Tanaman & 0-24 Hari \\
\hline 1 & 9 \\
\hline 2 & 10 \\
\hline 3 & 12 \\
\hline 4 & 12 \\
\hline 5 & 14 \\
\hline 6 & 12 \\
\hline 7 & 13 \\
\hline 8 & 9 \\
\hline 9 & 15 \\
\hline
\end{tabular}

Setelah itu dilakukan demontrasi pelatihan kepada warga Cianting Utara yang diwakili oleh mitra dari warga penggerak yaitu ibu-ibu PKK dan beberapa perangkat desa 


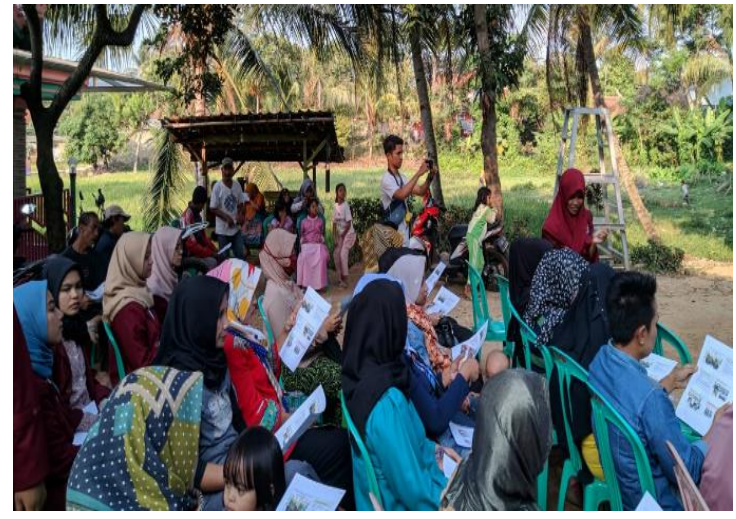

Gambar 5. Partisipasi Ibu-Ibu PKK dan perangkat desa dalam acara demontrasi pelatihan komposting padat

(Sumber: dokumentasi penulis)

Interaksi warga ditunjukkan dengan turut memperhatikan dan interaksi tanya jawab setiap pengarahan mengenai proses pembuatan komposting padat (Gambar 6).

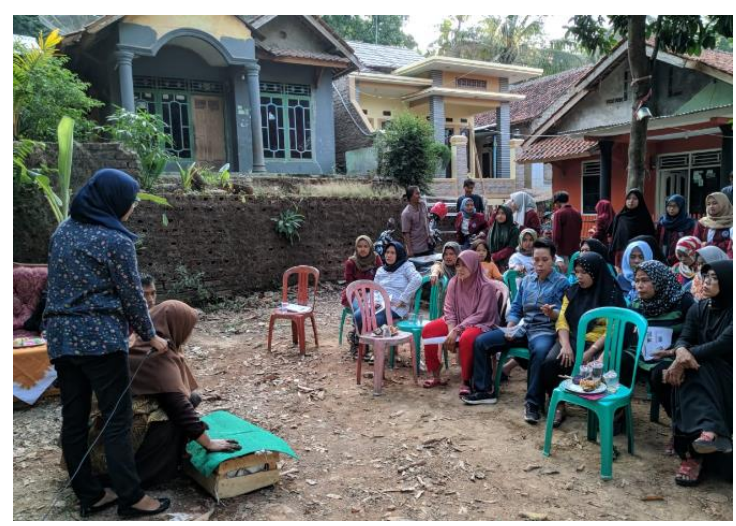

Gambar 6. Antusiasme ibu-ibu PKK dalam memperhatikan pengarahan dan tanya jawab (Sumber: dokumentasi penulis)

Indikator pengukuran diberikan berupa form kepada 15 koresponden yang ditunjuk selama mengikuti worshop dan kegiatan pengabdian:
Tabel 3. Penilaian Kepuasan

\begin{tabular}{ccccc}
\hline Indikator & \multicolumn{4}{c}{ Katgori } \\
\cline { 2 - 5 } & $\begin{array}{c}4-5 \\
\text { Sangat } \\
\text { Baik }\end{array}$ & $\begin{array}{c}3-4 \\
\text { Cukup } \\
\text { Baik }\end{array}$ & $\begin{array}{c}2-3 \\
\text { Baik }\end{array}$ & $\begin{array}{c}1-2 \\
\text { Kurang }\end{array}$ \\
\hline $\begin{array}{c}\text { Penyampaian } \\
\text { Tujuan }\end{array}$ & 13 & 2 & - & - \\
\hline $\begin{array}{c}\text { Komunikasi } \\
\text { Penyampaian } \\
\text { Materi }\end{array}$ & 14 & 1 & - & - \\
\hline $\begin{array}{c}\text { Implementasi } \\
\text { Praktek }\end{array}$ & 15 & 0 & - & - \\
\hline $\begin{array}{c}\text { Pengetahuan } \\
\text { Tanya Jawab }\end{array}$ & 12 & 3 & - & - \\
\hline
\end{tabular}

Evaluasi dari kegiatan tersebut dapat memberikan nilai-nilai diantaranya:

a. warga desa mitra (Cianting Utara) menjadi lebih teredukasi akan pemahaman pengelolaan sampah secara organik;

b. mampu mengimplementasikan cara pengolahan serta lebih termotivasi untuk merawat lingungan sekitar;

c. masyarakat bisa mengambil manfaat dari hasil yang diperoleh pada pekarangan masing-masing.

Sedangkan bagi tim pengabdian ini mampu mebuat tulisan artikel terpublikasi dan dapat menjadikan kelanjutan dari program ini berupa produksi komposting bersifat cair dari sampah organik sebagai pelengkap komposting padat.

\section{KESIMPULAN}

Kegiatan pembuatan komposting padat di Desa Cianting Utara, menghasilkan perkembangan yang terlihat dari tingkat kesuburan tanaman pada pengukuran panjang 
maksimal $14,5 \mathrm{~cm}$ dan jumlah daun rata-rata berjumlah 9-15 lembar daun serta dampak yang diterima masyarakat menjadi lebih proaktif dalam menangani masalah dilingkungannya. Berdasarkan pengukuran koresponden berjumlah 15 memberikan penilaian 98\% sangat baik pada empat kategori indikator. Sehingga dapat membantu kemandirian masyarakat sekitar dalam mengolah sampah minimal sampah organik rumah tangga yang mampu diimplementasikan di pekarangan pribadi.

\section{UCAPAN TERIMA KASIH}

Terima kasih kepada LPPM UNSIKA dan Dekan Fakultas Teknik serta Kaprodi Teknik atau Rekayasa Kimia dalam turut serta memberikan support bagi tim pengabdian masyarakat.

\section{DAFTAR PUSTAKA}

Banowati, E. (2011). Pengelolaan Sampah Berbasis Komunitas Untuk Konservasi Lingkungan [Laporan Penelitian]. Semarang: LP2M Unnes.

Dias. P.L. (2009). Fasilitas Pengolahan Sampah di TPA Jatibarang [Skripsi]. Fakutas Teknik Jurusan Arsitektur Universitas Diponegoro, Semarang.

Khuzzaman, U. A., Rahmayanti, H., \& Neolaka, A. (2018). Pengelolaan Sampah dengan Modifikasi Sanitary Landfill. Jurnal Menara, 8(1), 40-50.

Marfuatun. (2013). Potensi Pemanfaatan Sampah Organik. Yogyakarta: Pendidikan Kimia Universitas Negeri Yogyakarta.
Mehl, J. A., (2008). Pathogen Destruction and Anaerobic Decomposition in Composting Latrines: A Study from Rural Panama. Amerika Serikat: Michgan Technological University

Purwasasmita, M. \& Kurnia, K. (2009). Mikroorganisme Lokal sebagai Pemicu Siklus Kehidupan dalam Bioreaktor Tanaman. Seminar Nasional Teknik Kimia Indonesia SNTKI, Bandung.

Sony. (2008). Workshop on Community Based Solid Waste Management in Indonesia. Makalah, Jakarta: 16-17 Januari 2008. Balai Kartini.

Sutari, N.W.S. (2009). Pengujian Kualitas Bio Urine Hasil Fermentasi Dengan Mikroba yang Berasal dari Bahan Tanaman terhadap Pertumbuhan dan Hasil Tanaman Sawi (Brassica JunceaL) [Tesis]. Program Pasca Sarjana Universitas Udayana, Denpasar.

Sutrisno, E. \& Priyambada, I.B. (2019). Pembuatan Kompos Padat Limbah Kotoran Sapi dengan Metode Fermentasi Menggunakan Bioaktivator Stabio di Desa Ujung-Ujung Kecamatan Pabelan Kabupaten Semarang. Jurnal Pasopati, 1(2), 76-79.

Walidaini, R.A., Nugraha, W.D., Samudro, G. (2016). Pengaruh Penambahan Pupuk Urea dalam Pengomposan Sampah Organik secara Aerobik menjadi Kompos Matang dan Stabil Diperkaya. Jurnal Teknik Lingkungan, 5(2), 1 10. 